\title{
Analisis Kemampuan Pemecahan Masalah Matematika Setelah Pembelajaran dengan Pendekatan MEAs pada Materi Sistem Persamaan Linier Tiga Variabel
}

\author{
Hanifa Zulfitri $^{{ }^{*}}$, Nyimas Aisyah ${ }^{2}$ Indaryanti $^{3}$ \\ 1,2,3 Universitas Sriwijaya, Palembang, Sumatera Selatan 30139, Indonesia \\ Pengiriman: 14 Januari 2019; Diterima: 23 April 2019; Publikasi: 30 April 2019 \\ DOI: https://doi.org/10.31629/jg.v4i1.881
}

\begin{abstract}
Abstrak
Penelitian ini merupakan penelitian deskriptif kualitatif yang bertujuan untuk mengetahui kemampuan pemecahan masalah matematis siswa setelah pembelajaran dengan menggunakan pendekatan Model Eliciting Activities (MEAS) pada materi Sistem Persamaan Linier Tiga Variabel (SPLTV). Subjek dalam penelitian ini adalah siswa kelas X MIA 6 SMA Negeri 10 Palembang yang berjumlah 5 orang. Penelitian ini menggunakan teknik pengumpulan data berupa tes yaitu tiga soal pemecahan masalah materi SPLTV dan wawancara untuk memperoleh data secara mendalam. Hasil dalam penelitian ini menunjukkan bahwa indikator kemampuan pemecahan masalah yang sering muncul ialah indikator memahami masalah, dimana indikator ini muncul disetiap tingkat kemampuan siswa yaitu tinggi, sedang, dan rendah. Sedangkan indikator yang sangat jarang muncul ialah indikator melihat kembali. Dimana indikator ini hanya muncul pada tingkat kemampuan siswa yang tinggi saja, sedangkan untuk tingkat kemampuan siswa yang sedang dan rendah indikator ini tidak muncul. Penyebab indikator ini jarang muncul karena kebanyakan siswa tidak menghiraukan perintah soal untuk melihat kembali, siswa merasa cukup dengan perolehan hasil akhir tanpa menganalisis kembali hasil yang telah diperoleh.
\end{abstract}

Kata kunci: analisis; model eliciting activities; kemampuan pemecahan masalah

\begin{abstract}
This study is a qualitative descriptive research that aims to investigate the mathematical problem solving after learning with MEAs on linier equation system of three variables. The subjects of this research were 5 students of $X$ class of MIA 6 SMA Negeri 10 Palembang. The data of this study was collected by three items of problem solving test on SPLTV and through an interview to obtain the data deeply. The result of this study showed that the indicator of problem solving that the most often appeared was indicator of understanding the problem, where this indicator appeared at each level of ability of students, namely high, medium, and low. While indicator that was very rare to appear was indicator of looking back. This indicator which only appeared at the level of the ability of students was high, while for the the level of ability of students who were moderate and low, this indicator did not appear. The cause of this indicator rarely arose because most students ignored the command to look back, students felt enough to get the final results without re-analyzing the results that had been obtained.
\end{abstract}

Keywords: analysis; model eliciting activities; problem solving 


\section{JURNAL GANTANG. April 2019; IV(1): 7 - 13 \\ p-ISSN. 2503-0671 \\ e-ISSN. 2548-5547}

\section{Pendahuluan}

Pendidikan merupakan suatu usaha yang terencana untuk mewujudkan suasana belajar dan proses pembelajaran sehingga peserta didik dapat aktif mengembangkan potensi dirinya untuk memiliki kekuatan spiritual keagamaan, pengendalian diri, kepribadian, kecerdasan, akhlak mulia, serta keterampilan yang diperlukan dirinya, masyarakat, bangsa dan negara (Undang - Undang No.20 Tahun 2003 tentang Sisdiknas). Oleh karena itu, peserta didik diharapkan untuk dapat mengembangkan kemampuan kreatif, kritis, logis, dan sistematis. Kemampuan tersebut dapat dikembangkan melalui kegiatan pembelajaran matematika.

Adapun tujuan dari pembelajaran matematika menurut Permendiknas No. 22 Tahun 2006 adalah siswa mampu memiliki kemampuan pemecahan masalah yang terdiri dari kemampuan memahami masalah, merancang model matematika, menyelesaikan model dan menafsirkan solusi yang diperoleh (Kemendiknas, 2006). Sejalan dengan hal tersebut, National Council of Teachers of Mathematics (NCTM) mengemukakan kemampuan pemecahan masalah (problem solving) adalah salah satu tujuan pembelajaran matematika (NCTM, 2000). Berdasarkan uraian diatas terlihat bahwa salah satu tujuan pembelajaran matematika adalah siswa dapat memiliki kemampuan pemecahan masalah.

Menurut NCTM (2000) bahwa pemecahan masalah adalah salah satu yang tidak dapat dilepaskan dari pembelajaran matematika, dimana pemecahan masalah merupakan bagian terpenting dalam pembelajaran matematika. Sejalan dengan pendapat tersebut Ruseffendi (2006) juga mengungkapkan bahwa kemampuan pemecahan masalah sangat penting dalam matematika, dimana kemampuan pemecahan masalah dapat diterapkan dalam bidang studi dan dalam kehidupan sehari - hari. Berdasarkan uraian tersebut, kemampuan pemecahan masalah harus dimiliki siswa sehingga mereka dapat terlatih untuk menghadapi permasalahan baik masalah dalam bidang matematika atau masalah dalam bidang kehidupan sehari - hari. Oleh karena itu, kemampuan pemecahan masalah siswa perlu untuk ditingkatkan.

Namun pada kenyataannya kemampuan pemecahan masalah matematika siswa di Indonesia belum sejalan dengan pentingnya kemampuan pemecahan masalah matematika. Hal tersebut terlihat pada hasil survei Programme for International Student Assessment (PISA). Berdasarkan hasil studi PISA yang diselenggarakan tiap tahunnya, pada bidang matematika siswa Indonesia masih jauh dibawah rata - rata internasional, bahkan dibandingkan dengan negara tetangga seperti Malaysia dan Singapura. Hasil survei PISA pada tahun 2015 menunjukkn bahwa siswa Indonesia menempati peringkat ke 63 dari 72 negara dimana kemampuan dari siswa Indonesia hanya sampai level 4 saja (OECD, 2016). Hasil PISA yang rendah tentunya disebabkan oleh banyak faktor, salah satu faktor penyebabnya adalah siswa Indonesia umumnya kurang terlatih dalam menyelesaikan soal - soal pemecahan masalah (Wardhani \& Rumiati, 2011). Hal ini dikarenakan kebanyakan siswa Indonesia kurang berminat pada mata pelajaran matematika dikarenakan adanya kecenderungan yang ditampilkan kepada siswa adalah deretan rumus abstrak dan membosankan (Bintang Zaura \& Sulastri, 2012).

Berdasarkan permasalahan yang telah dijabarkan, perlunya suatu pendekatan pembelajaran matematika yang dapat meningkatkan kemampuan pemecahan masalah matematika siswa. Pendekatan pembelajaran yang cocok ialah Model Eliciting Activities (MEAs). Menurut Chamberlin \& Moon (2005) bahwa Model Eliciting Activities (MEAs) adalah pembelajaran yang menggunakan proses pemodelan matematika untuk memahami, menjelaskan, dan mengkomunikasikan konsep dari suatu masalah. Melalui MEAs, siswa dapat memahami konsep yang mereka pelajari, dimana masalah - masalah nyata kehidupan sehari - hari digunakan sebagai titik awal pembelajaran matematika (Suningsih, 2015). Berdasarkan hasil penelitian yang dilakukan Yu \& Chang (2009) 
bahwa MEAs berguna untuk meningkatkan kemampuan pemecahan masalah, dimana prinsip dan juga langkah pembelajaran MEAs ini dapat membantu siswa menjadi lebih aktif dan mengerti konsep - konsep dalam pembentukan model matematika dari permasalahan yang diberikan.

Salah satu materi yang ada pada pelajaran matematika adalah materi Sistem Persamaan Linier Tiga Variabel (SPLTV). Adapun Kompetensi Dasar (KD) pada materi ini adalah menyusun sistem persamaan linier tiga variabel dari masalah kontekstual yang berkaitan dengan sistem persamaan linier tiga variabel (Kemendikbud, 2017). Berdasarkan kompetensi dasar yang harus dicapai oleh siswa terlihat bahwa aplikasi materi SPLTV di kehidupan sehari - hari bisa dibilang cukup banyak. Sehingga kemampuan pemecahan masalah pada materi ini juga harus ditingkatkan dengan menggunakan Model Eliciting Activities (MEAs).

Berdasarkan paparan di atas, tulisan berikut akan menyajikan hasil analisis kemampuan pemecahan masalah matematika siswa setelah pembelajaran dengan pendektakan MEAs pada materi Sistem Persamaan Linier Tiga Variabel.

\section{Metode Penelitian}

Penelitian dilakukan selama 4 kali pertemuan dengan 3 kali pertemuan pembelajaran dengan menggunakan pendekatan pembelajaran Model Eliciting Activities (MEAs) dan 1 kali pertemuan tes tertulis yang bertujuan untuk mengukur kemampuan pemecahan matematika siswa.

Jenis penelitian yang digunakan adalah penelitian kualitatif dengan pendekatan deskriptif kualitatif. Fokus dalam penelitian ini adalah kemampuan pemecahan masalah siswa dalam menyelesaikan soal pemecahan masalah. Dimana kemampuan pemecahan masalah tersebut dianalisis berdasarkan indikator kemampuan pemecahan masalah. Subjek dalam penelitian ini adalah siswa kelas X MIA 6 SMA Negeri 10 Palembang. Kemudian subjek tersebut dikelompokkan berdasarkan hasil tes kemampuan pemecahan masalah dimana nilai dari hasil tes tersebut dikelompokkan berdasarkan kemampuan siswa yaitu tinggi, sedang, dan rendah. Pengelompokkan tersebut dilakukan dengan cara menyajikan nilai siswa dalam bentuk tabel distribusi data kelompok. Berikut tabel pembagian kelompok subjek:

Tabel 1

Pembagian kelompok siswa

\begin{tabular}{lcc}
\hline Kelompok & Rentang Nilai & Jumlah Siswa \\
\hline Tinggi & $100-79$ & 11 \\
\hline Sedang & $78-57$ & 18 \\
\hline Rendah & $56-35$ & 7 \\
\hline
\end{tabular}

Teknik pengumpulan data yang digunakan adalah tes tertulis dan wawancara. Tes dilakukan secara tertulis dengan soal berbentuk uraian. Tes dilaksanakan setelah melaksanakan pembelajaran dengan menggunakan pendekatan Model Eliciting Activities (MEAs). Jenis wawancara yang digunakan adalah wawancara semi-terstruktur. Wawancara dilakukan setelah tes kemampuan pemecahan masalah.

Uji kreadibilitas data pada penelitian ini dilakukan dengan triangulasi teknik. Triangulasi teknik dilakukan dengan cara membandingkan data berdasarkan teknik pengumpulan data dari suatu subjek. Analisis data dilakukan dengan berdasarkan analisis data kualitatif model Miles dan Huberman dalam Sugiyono (2015) yaitu sebagai berikut: data reduction (reduksi data), data display (penyajian data), dam conclusion/verification (penarikan kesimpulan).

\section{Hasil dan Pembahasan}

Berdasarkan hasil analisis data tes dan wawancara dari kelima subjek penelitian, tabel 1 memberikan rangkuman ketercapaian indikator kemampuan pemecahan masalah siswa dalam menyelesaikan soal pemecahan masalah materi SPLTV.

Berdasarkan tabel tersebut terlihat bahwa dari keempat indikator kemampuan pemecahan masalah, indikator yang paling sering muncul ialah indikator memahami masalah, dimana indikator ini muncul pada setiap tingkat kemampuan siswa yaitu tinggi, sedang, dan rendah. Sedangkan indikator kemampuan 
JURNAL GANTANG. April 2019; IV(1): 7 - 13

p-ISSN. 2503-0671

e-ISSN. 2548-5547

pemecahan masalah yang sangat jarang muncul ialah indikator melihat kembali. Dimana indikator ini hanya muncul pada tingkat kemampuan siswa yang tinggi saja, sedangkan untuk tingkat kemampuan siswa yang sedang dan rendah indikator ini tidak muncul. Adapun penyebabnya adalah berdasarkan data hasil catatan lapangan terlihat bahwa pada saat pembelajaran dengan menggunakan MEAs, siswa yang berkemampuan tinggi mengikuti proses pembelajaran dengan baik, dimana mereka aktif selama proses pembelajaran. Sedangkan siswa yang berkemampuan rendah tidak mengikuti proses pembelajaran dengan baik dimana mereka tidak aktif selama proses pembelajaran dan juga tidak serius dalam mengikuti proses pembelajaran.

Tabel 1.

Rangkuman ketercapaian indikator pemecahan masalah

\begin{tabular}{|c|c|c|c|c|c|}
\hline \multirow{2}{*}{ Subjek } & \multirow{2}{*}{ Nomor Soal } & \multicolumn{4}{|c|}{ Indikator } \\
\hline & & 1 & 2 & 3 & 4 \\
\hline \multirow{3}{*}{ S1 } & 1 & $\sqrt{ }$ & $\sqrt{ }$ & $\sqrt{ }$ & $\sqrt{ }$ \\
\hline & 2 & $\sqrt{ }$ & $\sqrt{ }$ & $\sqrt{ }$ & $\sqrt{ }$ \\
\hline & 3 & $\sqrt{ }$ & $\sqrt{ }$ & $\sqrt{ }$ & $\sqrt{ }$ \\
\hline \multirow{3}{*}{ S2 } & 1 & $\sqrt{ }$ & $\sqrt{ }$ & $\sqrt{ }$ & $\sqrt{ }$ \\
\hline & 2 & $\sqrt{ }$ & $\sqrt{ }$ & $\sqrt{ }$ & $\sqrt{ }$ \\
\hline & 3 & $\sqrt{ }$ & $\sqrt{ }$ & $\sqrt{ }$ & $\sqrt{ }$ \\
\hline \multirow{3}{*}{ S3 } & 1 & $\sqrt{ }$ & $\sqrt{ }$ & $\sqrt{ }$ & - \\
\hline & 2 & $\sqrt{ }$ & $\sqrt{ }$ & $\sqrt{ }$ & - \\
\hline & 3 & $\sqrt{ }$ & $\sqrt{ }$ & - & - \\
\hline \multirow{3}{*}{ S4 } & 1 & $\sqrt{ }$ & $\sqrt{ }$ & $\sqrt{ }$ & - \\
\hline & 2 & $\sqrt{ }$ & - & - & - \\
\hline & 3 & $\sqrt{ }$ & $\sqrt{ }$ & - & - \\
\hline \multirow{3}{*}{ S5 } & 1 & $\sqrt{ }$ & - & - & - \\
\hline & 2 & $\sqrt{ }$ & - & - & - \\
\hline & 3 & $\sqrt{ }$ & $\sqrt{ }$ & - & - \\
\hline
\end{tabular}

Indikator memahami masalah merupakan indikator pertama dalam kemampuan pemecahan masalah. Indikator memahami masalah muncul dilihat dari siswa mengerti apa yang diketahui untuk menyelesaikan soal dan apa yang ditanyakan oleh soal. Pada penelitian ini indikator memahami masalah merupakan indikator yang paling sering muncul, dimana indikator ini muncul pada semua subjek penelitian. Namun dalam indikator memahami masalah masil terdapat siswa yang kurang tepat dalam menginterpretasikan atau menuliskan apa yang diketahui dan ditanya soal, walaupun sebenarnya ia memahami apa yang dimaksud oleh soal tersebut. Hal tersebut terlihat dari jawaban subjek S1 berikut :

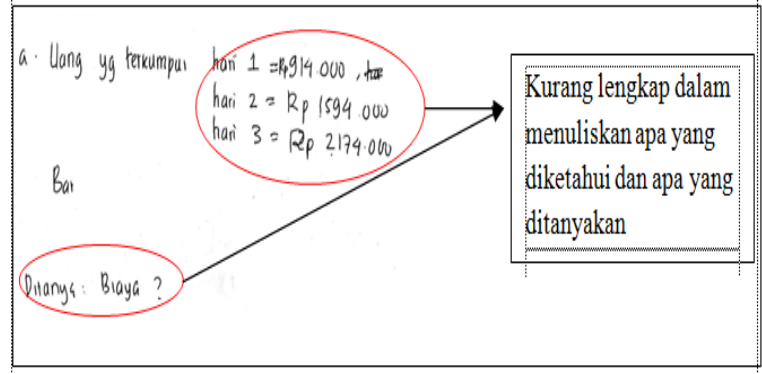

Gambar 1. Kurang tepat dalam menuliskan apa yang diketahui dan ditanya

Berdasarkan jawaban tersebut terlihat bahwa S1 kurang dalam mengidentifikasi informasi apa yang diketahui dan ditanya pada soal. Namun, pada saat wawancara S1 ternyata dapat menjelaskan dengan baik apa yang diketahui dan ditanya oleh soal. Berikut cuplikan wawancara S1 untuk indikator memahami masalah

P : Apa yang diketahui dan ditanyakan?

S1: Yang diketahui uang yang terkumpul pada hari pertama, kedua, dan ketiga sama banyak orang yang mendaftar pada hari pertama, kedua, dan ketiga. Yang ditanyakan adalah biaya kelas 1, 2, 3

Berdasarkan wawancara tersebut, terlihat bahwa S1 telah memahami masalah dimana dalam menjelaskan ia dapat mengidentifikasi apa yang diketahui dan ditanya dengan baik. Menurut pendapat Utami \& Wutsqa (2017) bahwa kemampuan siswa dalam menentukan apa yang diketahui dan ditanya merupakan indikator pemecahan masalah yang pertama dimana indikator ini merupakan indikator yang paling banyak dikerjakan oleh siswa. Namun sebagian siswa masih menunjukkan belum mampu menerapkan informasi pada soal untuk memecahkan masalah, siswa tidak mampu 
menganalisis informasi pada soal yang diberikan untuk memecahkan masalah, terlebih siswa banyak yang belum mampu menentukan kecukupan informasi soal.

Indikator membuat rencana merupakan indikator kedua dalam kemampuan pemecahan masalah. Indikator membuat rencana muncul dilihat dari siswa dapat menyederhanakan masalah, mendefinisikan variabel dengan baik, dan membuat model matematika dari suatu masalah. Pada penelitian ini, indikator ini muncul pada subjek kelompok tinggi dan kelompok sedang. Hasil penelitian menunjukkan bahwa subjek tidak dapat membuat rencana dengan baik ditunjukkan dari tidak tepat dalam membuat model matematika dari permasalahan, kurang tepat dalam mendefinisikan variabel, dan salah dalam mentransformasikan permasalahan. Adapun penyebab siswa kurang tepat dalam mendefinisikan variabel ialah siswa kurang tepat dalam mendefinisikan atau menginterpretasikan variabel dalam bentuk tulisan, namun sebenarnya siswa tersebut mengerti apa yang ia definisikan. hal tersebut terlihat dari jawaban subjek S5 berikut

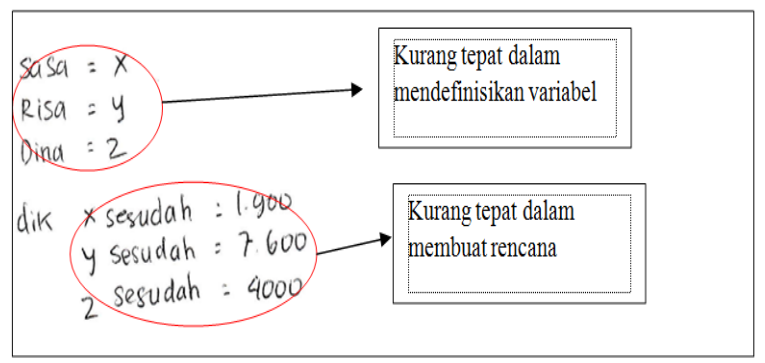

Gambar 2. Kurang tepat dalam mendefinisikan variabel

Berdasarkan jawaban tersebut terlihat bahwa S5 kurang dalam mendefinisikan variabel. Hal tersebut terlihat dari S5 hanya mendefinisikan variabel $x$ sebagai Sasa, $y$ sebagai Risa, dan $z$ sebagai Dina, seharusnya $x$ sebagai uang yang dimiliki Sasa diputaran kedua, $y$ sebagai uang yang dimiliki Risa diputaran kedua, dan $z$ sebagai uang yang dimiliki Dina diputaran kedua. Namun, pada saat wawancara ternyata S5 dapat menjelaskan dengan baik alur dalam menyelesaikan soal. Adapun cuplikan wawancara
S5 untuk indikator membuat rencana

$\mathrm{P}$ : Bagaimana kamu mencari uang mereka dironde kedua?

S5 : Memisalkan uang mereka dulu

$\mathrm{P}$ : Apa yang dimisalkan?

S5 : Sasa itu sebagai $x$, Risa sebagai $y$, dan Dina sebagai $z$

Berdasarkan wawancara tersebut, terlihat bahwa S5 kurang tepat mendefinisikan variabel dalam bentuk tulisan. Hal tersebut diakibatkan karena siswa masih kurang dalam mendefinisikan ide ke dalam bentuk matematika. Hal tersebut sejalan dengan pendapat Mujulifah (2015) bahwa dalam aspek komunikasi aljabar, siswa masih belum lancar dalam mengekspresikan ide ke dalam bahasa matematika.

Sedangkan penyebab siswa kurang tepat dalam membuat model matematika adalah kekeliruan dalam mengartikan informasi soal dimana ia masih keliru dalam menginterpretasikan konteks nyata ke dalam model matematika. Hal tersebut terlihat dari jawaban subjek S4 berikut

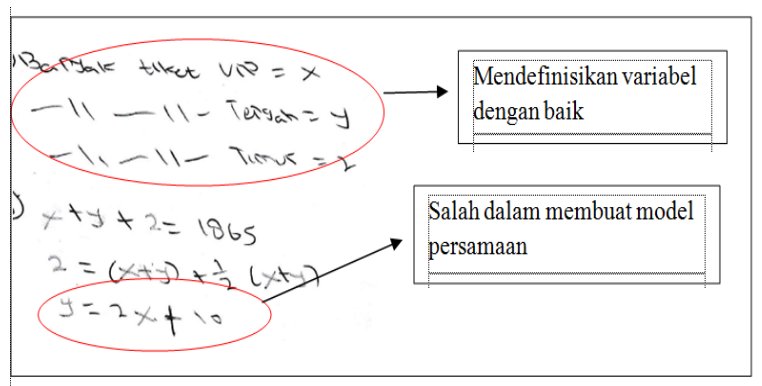

Gambar 3. Kurang tepat dalam membuat model persamaan

Berdasarkan jawaban yang telah dituliskan S4 untuk soal nomor 2, terlihat bahwa S4 kurang dalam membuat rencana. Hal tersebut terlihat dari S4 salah dalam membuat salah satu model persamaan, dimana ia menuliskan $y=$ $2 x+10$ yang seharusnya adalah $y=2 x-10$. Berikut cuplikan wawancara peneliti dan S4 untuk indikator membuat rencana :

$\mathrm{P}$ : Bisa jelaskan gak persamaan $y=2 x+$ 10 maksudnya apa?

S4 : Itu persamaan tiket tribun timur, katanya 10 tiket lebih sedikit dari 2 kali banyak 


\section{JURNAL GANTANG. April 2019; IV(1): 7 - 13 \\ p-ISSN. 2503-0671 \\ e-ISSN. 2548-5547}

tiket VIP

$\mathrm{P} \quad$ : Kira - kira benar gak persamaannya?

S4 : Insyaallah benar bu

Berdasarkan wawancara tersebut, S4 tidak menyadari bahwa model persamaan yang ia buat adalah salah. Hal tersebut diakibatkan S4 salah dalam mengartikan maksud soal atau dengan kata lain S4 salah dalam mengidentifikasi informasi. Berdasarkan hasil penelitian Edo (2013) mengatakan bahwa siswa masih kesulitan dalam proses merumuskan masalah dalam kehidupan sehari - hari ke dalam model matematika seperti menginterpretasikan konteks situasi nyata kedalam bentuk model matematika.

Indikator melaksanakan rencana merupakan indikator ketiga dalam kemampuan pemecahan masalah. Indikator melaksanakan rencana muncul dilihat dari siswa mampu menyelesaikan masalah dengan baik dan benar. Pada penelitian ini, indikator ini muncul pada subjek kelompok tinggi dan hanya beberapa yang muncul pada subjek kelompok sedang. Hasil penelitian menunjukkan bahwa subjek tidak dapat menyelesaikan masalah dengan baik ditunjukkan dari kekeliruan dalam penyelesaian masalah dan siswa tidak selesai dalam menyelesaikan masalah atau dalam artian proses penyelesaian terhenti.

Adapun penyebab siswa keliru dalam penyelesaian masalah ialah siswa salah dalam membuat rencana pada indikator pemecahan masalah yang kedua sehingga proses penyelesaian masalah juga salah dan kekeliruan dalam proses perhitungan. Selain itu, penyebab proses penyelesaian tidak selesai atau dengan kata lain proses penyelesaian terhenti adalah waktu dalam pengerjaan soal sehingga banyak siswa yang tidak selesai dalam menyelesaikan masalah.

Indikator melihat kembali merupakan indikator keempat dalam kemampuan pemecahan masalah. Indikator ini muncul dilihat dari siswa dapat mengecek semua perhitungan dan solusi yang telah diperoleh. Pada penelitian ini, indikator melihat kembali merupakan indikator yang paling jarang muncul, dimana indikator ini hanya muncul pada subjek kelompok tinggi saja.

$$
\text { Menurut Utami \& Wutsqa (2017) }
$$

kemampuan pemecahan masalah dalam tahap melihat kembali dapat ditunjukkan pada saat siswa mensubtitusikan hasil yang telah diperoleh ke salah satu persamaan yang ada. Presentase kemampuan siswa dalam indikator ini paling kecil dibandingkan dengan indikator lainnya. Kebanyakan siswa tidak menghiraukan perintah soal untuk tahap melihat kembali, siswa merasa cukup dengan perolehan hasil akhir tanpa menganalisis kembali hasil yang telah diperoleh. Berdasarkan hasil penelitian ini, kebanyakan siswa dalam melihat kembali, ia hanya melihat saja perhitungan yang ia lakukan tanpa benar benar memeriksanya. Selain itu, berdasarkan hasil penelitian terdapat siswa yang tidak selesai dalam dalam melaksanakan penyelesaian atau pada indikator melaksanakan rencana dalam kemampuan pemecahan masalah. Hal tersebut mengakibatkan ia tidak memperoleh hasil atau kesimpulan akhir dalam penyelesaiannya. Sehingga ia tidak dapat melaksanakan indikator melihat kembali.

\section{Kesimpulan}

Berdasarkan temuan dan pembahasan, maka peneliti dapat mengambil kesimpulan bahwa kemampuan pemecahan masalah siswa setelah pembelajaran dengan pendekatan Model Eliciting Activities (MEAs) pada materi Sistem Persamaan Linier Tiga Variabel (SPLTV) dikatakan baik. Dimana indikator yang dapat muncul ialah indikator memahami masalah, indikator membuat rencana, dan indikator melaksanakan rencana. Sedangkan indikator yang tidak muncul ialah indikator melihat kembali.

Indikator pemecahan masalah yang paling dominan adalah indikator memahami masalah. Dimana indikator ini muncul disetiap kelompok subjek yaitu tinggi, sedang, dan rendah. Dalam indikator memahami masalah masih terdapat siswa yang kurang dalam menafsirkan atau menuliskan apa yang diketahui. Sedangkan indikator kemampuan pemecahan masalah yang sedikit muncul ialah indikator melihat kembali. Diman indikator ini hanya muncul pada kelompok subjek tinggi saja. Adapun penyebabnya adalah pada saat pembelajaran dengan MEAs siswa yang berkemampuan tinggi 
mengikuti proses pembelajaran dengan sangat baik dan aktif selama pembelajaran. Dalam indikator melihat kembali, siswa hanya melihat saja perhitungan yang ia lakukan tanpa benar benar memeriksanya dan terdapat siswa yang tidak selesai dalam melaksanakan rencana dalam kemampuan pemecahan masalah.

\section{Referensi}

Bintang Zaura, \& Sulastri. (2012). Model pembelajaran kooperatif tipe STAD sebagai upaya meningkatkan hasil belajar siswa pada materi barisan dan deret bilangan di kelas IX SMP Negeri 1 Labuhanhaji Aceh Selatan. Jurnal Peluang, 1(1), 21-29.

Chamberlin, S. A., \& Moon, S. M. (2005). Modeleliciting activities as a tool to develop and identify creatively gifted mathematicians. Journal of Secondary Gifted Education, 17(1), $37-47$. https://doi.org/10.4219/jsge-2005-393

Edo, S. I., Ilma, R., \& Hartono, Y. (2013). Investigating secondary school students' difficulties in modeling problems PISAmodel level 5 And 6. Journal on Mathematics Education, 4(1). https://doi.org/10.22342/jme.4.1.561.4158

Kemendikbud. (2017). Matematika Kelas X SMA/MA/SMK Revisi 2017. Jakarta: Kementerian Pendidikan dan Kebudayaan.

Kemendiknas. (2006). Permendiknas No 22 Tahun 2006 Tentang Standar Isi untuk Satuan Pendidikan Dasar dan Menengah. Mujulifah, F. (2015). Literasi matematis siswa dalam menyederhanakan ekspresi aljabar. Jurnal Pendidikan dan Pembelajaran, 4(1), 12.

NCTM (Ed.). (2000). Principles and standards for school mathematics. Reston, VA: NCTM.

OECD. (2016). PISA 2015 Results (Vol. 1). Diambil dari http://dx.doi.org/10.1787/978926426649 0 -en
Ruseffendi. (2006). Pengantar kepada membantu guru mengembangkan kompetensinya dalam pengajaran matematika untuk meningkatkan CBSA. Bandung: Tarsito.

Sugiyono. (2015). Metode penelitian kuantitatif, kualitatif, dan $R \& D$. Bandung: Alfabeta.

Suningsih, A. (2015). Pembelajaran garis lurus dengan model eliciting activities dan team assisted individualization ditinjau dari gaya kognitif. Jurnal e-DuMath, $1(1), 34-42$.

Utami, R. W., \& Wutsqa, D. U. (2017). Analisis kemampuan pemecahan masalah matematika dan self-efficacy siswa SMP negeri di Kabupaten Ciamis. Jurnal Riset Pendidikan Matematika, 4(2), 166. https://doi.org/10.21831/jrpm.v4i2.1489 7

Wardhani, S., \& Rumiati. (2011). Instrumen penilaian hasil belajar matematika SMP : belajar dari PISA dan TIMSS. Jakarta: Pusat Pengembangan dan Pemberdaya Pendidikan dan Tenaga Kependidikan (PPPPTK).

Yu, S.-Y., \& Chang, C.-K. (2009). What did taiwan mathematics teachers think of model-eliciting activities and modeling? ICTMA, 14, 9. 
JURNAL GANTANG. April 2019; IV(1): 7 - 13

p-ISSN. 2503-0671

e-ISSN. 2548-5547 